\title{
Hypoxia-inducible factor-1 $\alpha$ expression and gemcitabine chemotherapy for pancreatic cancer
}

\author{
KAZUHIKO KASUYA ${ }^{1}$, AKIHIKO TSUCHIDA ${ }^{1}$, YUICHI NAGAKAWA ${ }^{1}$, MINAKO SUZUKI $^{1}$, YUTA ABE $^{2}$, \\ TAKAO ITOI $^{3}$, HIROMI SERIZAWA ${ }^{4}$, TOSHITAKA NAGAO ${ }^{5}$, MOTOHIDE SHIMAZU ${ }^{2}$ and TATSUYA AOKI ${ }^{1}$ \\ ${ }^{1}$ Department of Digestive Surgery, Tokyo Medical University; ${ }^{2}$ Department of Digestive Surgery, Tokyo Medical University \\ Hachioji Medical Center; ${ }^{3}$ Department of Internal Medicine, Tokyo Medical University; ${ }^{4}$ Department of Pathology, Tokyo \\ Medical University Hachioji Medical Center; ${ }^{5}$ Department of Pathology, Tokyo Medical University, Tokyo, Japan
}

Received May 25, 2011; Accepted August 2, 2011

DOI: $10.3892 /$ or.2011.1457

\begin{abstract}
The normal pancreas has an abundant blood flow, in contrast to pancreatic cancer, which is a hypovascular tumor. During hypoxia under a hypovascular environment, the transcription factor hypoxia-inducible factor-1 $\alpha$ (HIF-1 $\alpha)$ is activated. High HIF-1 $\alpha$ expression reduces sensitivity to gemcitabine (GEM) which is used as a treatment for pancreatic cancer. The objective of this study was to clarify HIF-1 $\alpha$ expression in pancreatic cancer and the association of its effects to GEM treatment. We used the human pancreatic ductal carcinoma cell lines AsPC-1 and BxPC-3 to evaluate cell proliferation, HIF-1 $\alpha$ protein expression and sensitivity to GEM in a hypoxic environment of $1 \% \mathrm{O}_{2}$ in 48 pancreatic cancer patients who received adjuvant GEM treatment after pancreatectomy. We divided the patients according to HIF-1 $\alpha$ expression and the presence of single nucleotide polymorphisms, and we based our evaluation on the adverse events associated with GEM chemotherapy and patient outcome. The hypoxic environment promoted cell proliferation, induced HIF-1 $\alpha$ expression and increased GEM resistance, especially in AsPC-1 cells, which included a mutant homozygote for HIF- $1 \alpha(\mathrm{C} 1772 \mathrm{~T})$. There were no significant differences between the HIF-1 $\alpha(-)$ and HIF-1 $\alpha(+)$ groups in either adverse events or patient outcomes. HIF-1 $\alpha$ enhanced neo-microvascularity in a hypoxic environment and increased drug resistance. The period until recurrence was shorter in the patients with a strong HIF-1 $\alpha$ expression, than that in those with a weak HIF-1 $\alpha$ expression.
\end{abstract}

\section{Introduction}

The normal pancreas has an abundant blood flow in contrast to pancreatic cancer, which is a hypovascular tumor. This

Correspondence to: Dr Kazuhiko Kasuya, Department of Digestive Surgery, Tokyo Medical University, 6-7-1 Nishishinjuku, Shinjuku-ku, Tokyo 160-0023, Japan

E-mail:kasuya-k@jcom.home.ne.jp

Key words: HIF-1 $\alpha$, gemcitabine, pancreatic cancer, SNP is partly because of fibrotic changes around the cancer due to pancreatitis associated with cancer invasion. Fibroblast migration to fibrotic tissues and inflammatory cell infiltration induce the expression of various cytokines, which increases pancreatic cancer invasion and malignancy. Hypoxiainducible factor- $1 \alpha$ (HIF-1 $\alpha)$ is a transcription factor that is activated during hypoxia in a hypovascular environment (1). HIF- $1 \alpha$ is ubiquitinated by the Von Hipple-Lindau (VHL) protein under normoxic conditions and is quickly degraded by proteasomes. However, HIF-1 $\alpha$ expression in hypoxia can escape proteasome degradation, and HIF-1 $\alpha$ shows transcriptional activity which induces various factors (1), one of which is the vascular endothelial growth factor (VEGF). High-level VEGF expression induces microvascular proliferation around the tumor, promoting cancer malignancy. The level of HIF-1 $\alpha$ expression differs among individuals according to the presence or absence of $\mathrm{C} 1772 \mathrm{~T}(\mathrm{C} \rightarrow \mathrm{T}$ mutation) or G1790A $(\mathrm{G} \rightarrow \mathrm{A}$ mutation) as single nucleotide polymorphisms (SNPs) in exon 12 , the region of transcriptional activity and of the binding site to VHL protein. A large number of tumor blood vessels have been reported in patients with head or neck cancer showing SNPs in this region (2). In addition, high-level HIF-1 $\alpha$ expression reduces sensitivity to gemcitabine (GEM) as a drug for pancreatic cancer $(3,4)$. In the present study, we clarified the characteristic of HIF- $1 \alpha$ expression in pancreatic cancer and its associated effects with GEM.

Written informed consent was obtained before the analysis after a thorough explanation was given to the patients. This study was approved by the Ethics Committee of the Tokyo Medical University.

\section{Materials and methods}

Cell lines and assays. The human pancreatic ductal carcinoma cell lines AsPC-1 and BxPC-3 were purchased from the American Type Culture Collection (Manassas, VA). Cells were cultured at $37^{\circ} \mathrm{C}$ in RPMI-1640 (Gibco, Life Technologies Japan Ltd., Tokyo, Japan) supplemented with $10 \%$ fetal calf serum (FCS; Sigma, St. Louis, MO) in a humidified atmosphere containing $5 \% \mathrm{CO}_{2}$. For cell viability assay, cells were cultured in 96-well microplates for $24 \mathrm{~h}$ at a volume of $100 \mu \mathrm{l}$ 

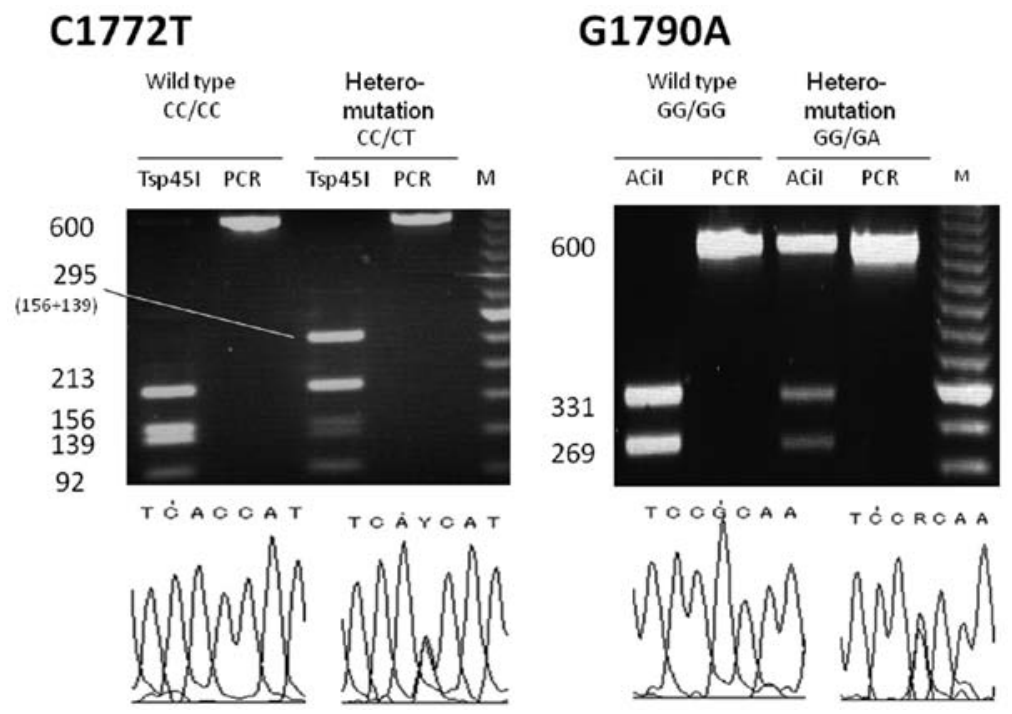

Figure 1. Digestion of the PCR product by restriction enzymes. (a) The PCR product of $600 \mathrm{bp}$ was digested to 213, 156, 139 and $92 \mathrm{bp}$ in the wild-type of C1772C by Tsp45I, but was in addition digested to $295 \mathrm{bp}$ in the heterovariant of C1772C/T. (b) The same PCR product was digested to 331 and $269 \mathrm{bp}$ in the wild-type G1790G by AciI, but half of the product was undigested and remained intact with the heterovariant of G1790G/A. These results were confirmed by direct DNA sequencing.

$(10,000$ cells/well $)$ at $37^{\circ} \mathrm{C}$ in a humidified atmosphere of $5 \% \mathrm{CO}_{2}$. When the cells became adherent to the plates, the plates were transferred to an environment of either $1 \%$ or $20 \% \mathrm{O}_{2}$, and incubated for $24 \mathrm{~h}$. To evaluate the viability of AsPC- 1 and BxPC- 3 cells in a hypoxic atmosphere, we used methyltetrazolium (MTT; 3[4,5-dimethyl-thiazoyl-2-yl]2,5diphenyl-tetrazoliumbromide; Sigma). Cells were cultured in 96-well microplates and irradiated for $24 \mathrm{~h}$. MTT (10 $\mu \mathrm{l}$ of a $5 \mathrm{mg} / \mathrm{ml}$ solution in phosphate-buffered saline) was added to each well, followed by incubation for $4 \mathrm{~h}$. Finally, $100 \mu \mathrm{l}$ of acid-isopropanol was added to each well to solubilize MTT formazan. After complete solubilization of the dye by vortexing the plate, an absorbance was read on an Immunoreader (Powerscan HT, DS Pharma Biomedical Co., Ltd., Osaka, Japan) at an optical density of $570 \mathrm{~nm}$. For the HIF-1 $\alpha$ enzyme-linked immunosorbent assay (ELISA), when the cells became adherent to the plate, the plates were transferred to an environment of either $1 \%$ or $20 \% \mathrm{O}_{2}$ and incubated for $24 \mathrm{~h}$. To evaluate the HIF-1 $\alpha$ expression of AsPC-1 and BxPC-3 cells in a hypoxic atmosphere, we used a cell-based ELISA of human total HIF-1 $\alpha$ (R\&D Systems Inc., Minneapolis, MN). In this assay method, cells were simultaneously incubated with 2 primary antibodies: a HIF-1 $\alpha$ protein-specific antibody and a cytochrome-c-specific normalization antibody, a housekeeping protein. The fluorescence of HIF-1 $\alpha$ protein expression on the cells was normalized to that of the housekeeping protein. To evaluate the sensitivity of AsPC-1 and BxPC-3 cells to GEM, a suspension of these cells in a serum-free medium was placed in 96-well plates at a volume of $90 \mu \mathrm{l}(2,000$ cells/well $)$ at $37^{\circ} \mathrm{C}$. When the cells became adherent to the plate $24 \mathrm{~h}$ later, GEM was added at concentrations of $0-1 \mu \mathrm{M}$ and incubated for a further $24 \mathrm{~h}$. Cell survival was measured using a WST-1 Cell Counting kit (Wako Co., Ltd., Osaka, Japan). This kit evaluates cell viability as a percentage of untreated controls.

Patients and chemotherapy. Of the 48 patients in this study, 39 received adjuvant GEM treatment after pancreatectomy for pancreatic cancer at Tokyo Medical University Hospital between June 2004 and March 2008, and 9 received the same treatment at Tokyo Medical University Hachioji Medical Center between April 2008 and March 2010. GEM was given on days 1 and 15 for 4 weeks to patients indicated for $\mathrm{R}=0$ or $\mathrm{R}=1$ resection. Patients with greater than grade 2 (G2) adverse events according to the Common Terminology Criteria for Adverse Events version 3.0 (CTCAE v.3) were given a granulocyte-colony stimulating factor (G-CSF) or an anti-nausea drug. The patients in the $\mathrm{R}=0$ or $\mathrm{R}=1$ resection group received the maximum dose of GEM medication until recurrence.

Single nucleotide polymorphisms of HIF-1 $\alpha$. Genomic DNA was isolated from the pancreatic cancer cell lines and peripheral lymphocytes from the venous blood $(2 \mathrm{ml})$ of patients using the QIAamp DNA Blood kit (Qiagen Inc., Valencia, CA). The DNA target sites were amplified by polymerase chain reaction (PCR) which was performed to a total volume of $50 \mu \mathrm{l}$ in the presence of $100 \mu \mathrm{g}$ of cDNA (SuperMix; Invitrogen Corp., Carlsbad, CA), and $0.25 \mu \mathrm{M}$ of the forward (5'-TTGCTGAAGACACAGAAGCAA-3') and reverse primers (5'-TGTTATCTGTCGCTTTGAGTCAA-3'). After an initial denaturation, 37 cycles of $1 \mathrm{~min}$ at $94^{\circ} \mathrm{C}, 1 \mathrm{~min}$ at $55^{\circ} \mathrm{C}$ and $1 \mathrm{~min}$ at $72^{\circ} \mathrm{C}$, followed by $1 \mathrm{~min}$ at $68^{\circ} \mathrm{C}$ and a final extension period were performed. The PCR product (600 bp) was digested by appropriate restriction enzymes $T s p 45 \mathrm{I}$ and AciI (New England Biolabs Inc., Ipswich, MA) under its standard condition to screen the target site of SNPs [HIF-1 $\alpha(1772)$ and HIF-1 $\alpha(1790)$ in exon 12]. Each SNP was confirmed by restriction fragment length polymorphism under electrophoresis on 5\% agarose gels to confirm the size of fragments, at a constant power of $150 \mathrm{~V}$ for $1-4 \mathrm{~h}$, according to the fragment size. SNPs of $\mathrm{C} \rightarrow \mathrm{T}$ mutation occurred at HIF-1 $\alpha(1772)$. The PCR product was digested by $T s p 45 \mathrm{I}$ to $213,156,139$ and 92 bp at C1772C (wild-type). The same product with the heterogeneous mutation $(\mathrm{C} 1772 \mathrm{~T})$ showed these as well as a $295 \mathrm{bp}$ fragment. 

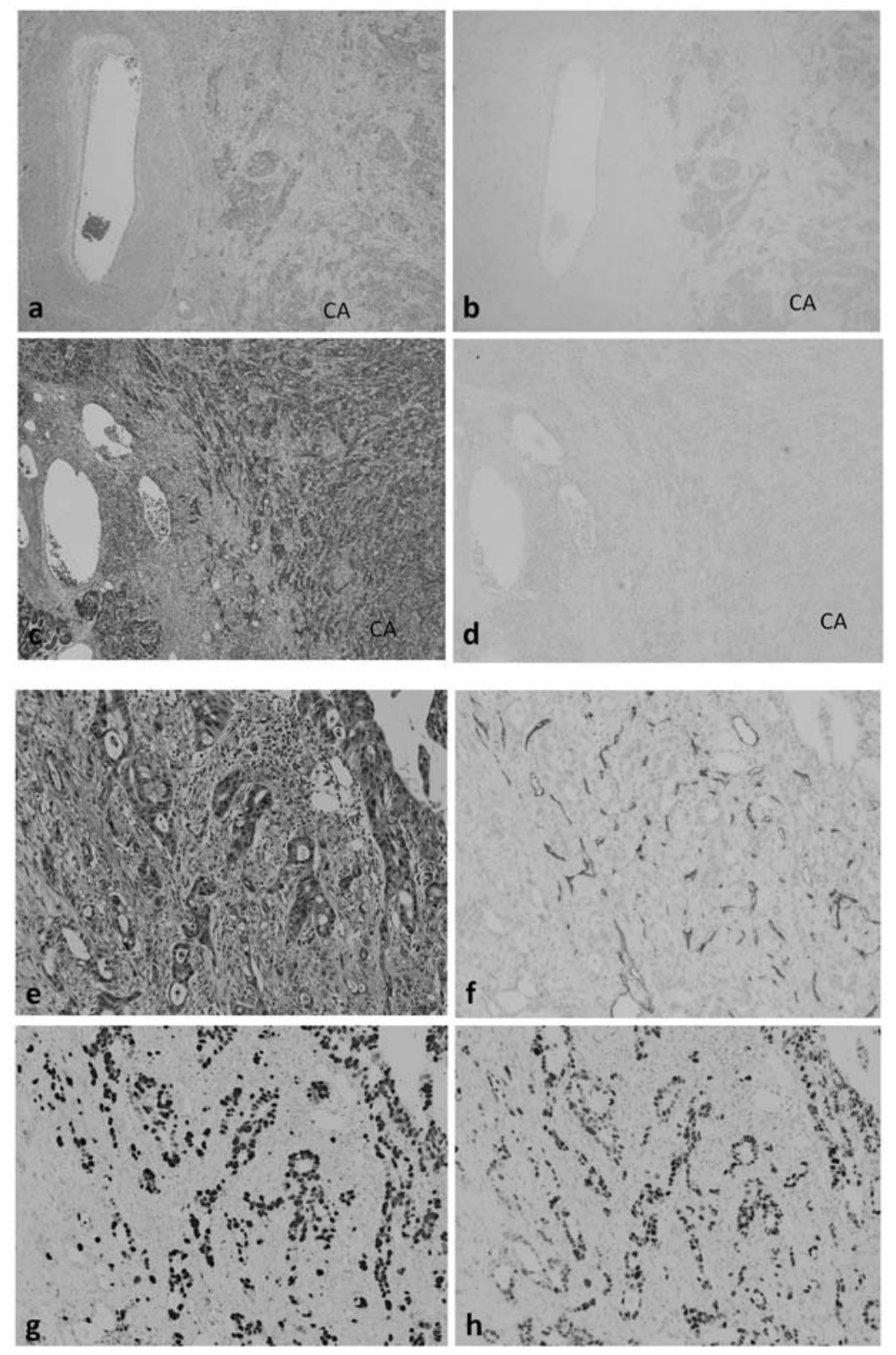

Figure 2. Pancreatic cancer infiltration areas with inflammation viewed with (a, c and e) hematoxylin and eosin (H\&E) and (b and d) HIF-1 $\alpha$ staining. Magnification, x200. Serial sections from the same specimen are shown in (a and b) and (c and d). (b) Positive HIF-1 $\alpha$ expression. (a and b) Cancer cells can be seen on the right half of the specimen. (b) HIF-1 $\alpha$ immunoreactivity in the cancerous area was stronger than that in the stromal area. (d) Negative HIF-1 $\alpha$ expression. HIF-1 $\alpha$ immunoreactivity in the cancer area was weak, similar to that in the stromal area. (f) CD34 staining, (g) Ki-67 staining and (h) p53 staining. CA, cancer.

SNPs of $\mathrm{G} \rightarrow \mathrm{A}$ mutation occurred at HIF-1 $\alpha(1790)$. The PCR product was digested by AciI to 331 and 269 bp at G1790G (wild-type). The same product with heterogeneous mutation (G1790A) showed these as well as a 600 bp fragment. The mutations in these genes described above were confirmed by analyzing DNA sequences directly on a 3730 DNA Analyzer (Applied Biosystems) using a Big-Dye Terminator V 3.1 Cycle Sequencing kit (Applied Biosystems). The sequencing primers were the same as those used in the PCR amplifications (Fig. 1). We assumed that patients who had a mutation of either HIF-1 $\alpha(1772)$ or HIF-1 $\alpha(1790)$, or both, to be HIF-1 $\alpha$ SNP-positive.

Immunohistochemistry. The surgical specimens were fixed in $10 \%$ formalin and embedded in paraffin for routine histo- logical diagnosis with hematoxylin and eosin (H\&E) staining. Immunostaining of CD34, which is found in vascular endothelial cells, and p53, Ki-67 and HIF-1 $\alpha$ immunostaining were performed using serial specimens. They were inactivated of their endogenous peroxidase with 3\% hydrogen peroxide and non-specific antibody binding, and then incubated with the DO7 anti-human p53 mouse monoclonal antibody (MoAb) (Dako, Glostrup, Denmark), which recognizes both wild- and mutant-type 533 proteins, with MIB1 anti-human Ki-67 MoAb (Immunotech, Marseille, France), which recognizes proliferative cells, and with H-1 $\alpha 67$ HIF-1 $\alpha$ MoAb (Novus Biologicals, Inc., Littleton, $\mathrm{CO}$ ) for $30 \mathrm{~min}$ at room temperature. Excess antibodies were washed out and the specimens were incubated with secondary biotinylated anti-rabbit antibodies (LSAB2 kit: Dako), avidin-biotin complex and 3,3'-diaminobenzidine. The 

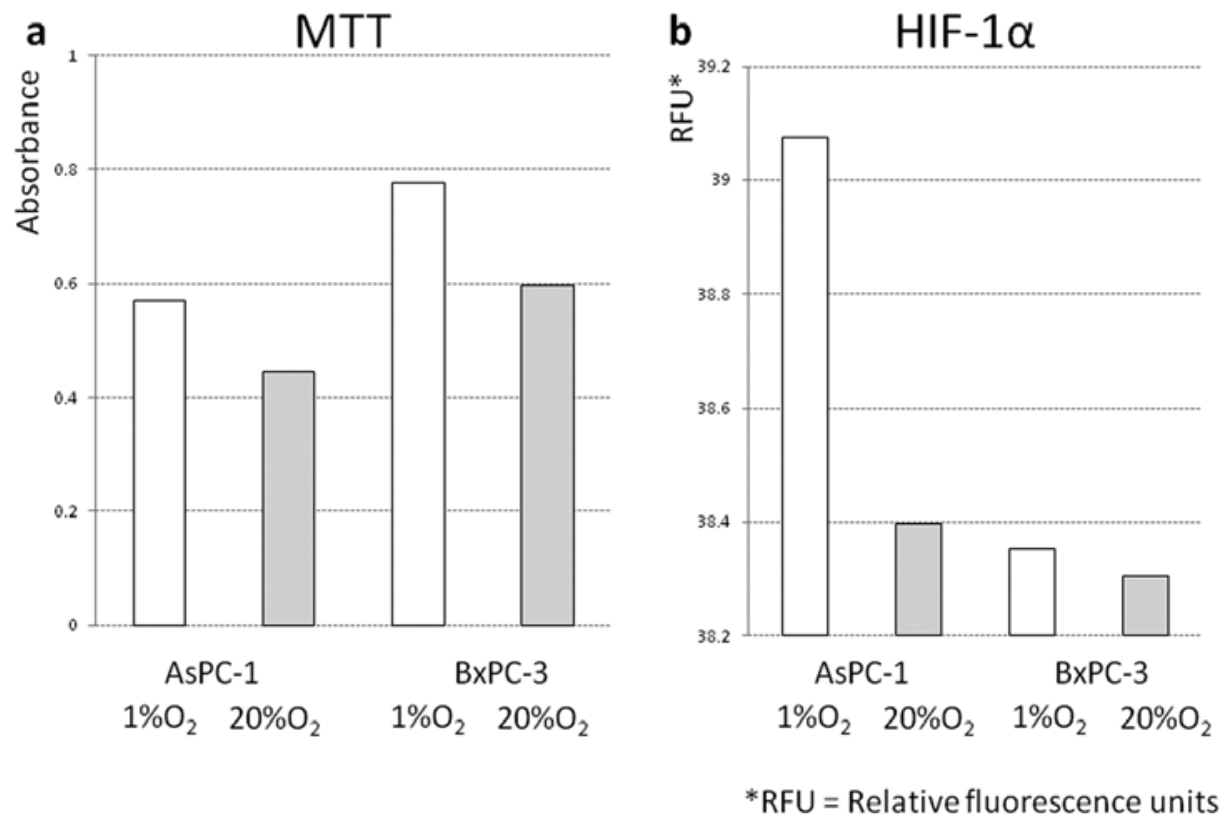

Figure 3. Cell viabilities in $1 \%$ (white bars) and $20 \%$ (gray bars) $\mathrm{O}_{2}$ environment (a). The hypoxic environment induced HIF-1 $\alpha$ expression from AsPC-1. HIF-1 $\alpha$ expression levels per cell in $1 \% \mathrm{O}_{2}$ (white bar) and $20 \% \mathrm{O}_{2}$ environment (gray bar) (b).

Table I. Pancreatic cell line characteristics.

\begin{tabular}{lcc}
\hline Variables & AsPC-1 & BxPC-3 \\
\hline HIF-1 $\alpha$ SNPs & C1772T/C & GC1790G/A \\
MTT (Hypoxia/control ${ }^{\mathrm{a}}$ ) & $>1$ & $>1$ \\
HIF-1 $\alpha$ protein expression & & + \\
Hypoxia & ++ & + \\
Control $^{\mathrm{a}}$ & + & + \\
GEM resistance $^{\text {Hypoxia }}$ & & - \\
Control $^{\mathrm{a}}$ & ++ & + \\
\hline
\end{tabular}

++ , strong positive; + , weak positive; -, negative. ${ }^{\mathrm{a}} 20 \% \mathrm{O}_{2}$ environment.

specimens were then counterstained with hematoxylin. For p53 labeling, $70 \%$ or more of nuclei with an intensity that was clearly demarcated from the surrounding mucosa at low power magnification was evaluated as positive. Immunoreactivity of Ki-67 was evaluated by the labeling index (LI), defined as the percentage of $\mathrm{Ki}$-67-positive cells in more than 1,000 tumor cells, including the peripheral field of each tumor. When staining for HIF-1 $\alpha$, nuclei or cytoplasmic staining was evaluated as positive. We assumed almost all cancer cells which showed strong positivity to be HIF-1 $\alpha$-positive (Fig. 2).

Statistical analysis. Statistical analyses were performed using StatView (Abacus Concepts Inc., Berkeley, CA). The MannWhitney-U test was used for MTT and WST-1 assays against GEM, HIF-1 $\alpha$ ELISA, CD34-positive vessel counts and MIB1 LI. The $\chi^{2}$ test was used for $\mathrm{p} 53$ protein overexpression and data on GEM medication disorders. The overall survival (OS) and disease-free survival (DFS) probabilities were estimated using the Kaplan-Meier method with log-rank tests from the initial date of surgical resection. A two-sided P-value of $<0.05$ was considered to represent a statistically significant difference.

\section{Results}

Cell viabilities are shown in Fig. 3a. The absorbance of AsPC-1 was 0.57 in a $1 \% \mathrm{O}_{2}$ environment and 0.44 in a $20 \% \mathrm{O}_{2}$ environment. The absorbances of $\mathrm{BxPC}-3$ were 0.78 and 0.60 , respectively. This trend continued until $72 \mathrm{~h}$ later (unpublished data). The data shown are the means of 3 experiments. These data suggest that the hypoxic environment promoted cell proliferation.

HIF-1 $\alpha$ expression levels per cell are shown in Fig. 3b. The relative fluorescence unit (RFU) of AsPC-1 was 39.07 in the $1 \% \mathrm{O}_{2}$ environment and 38.40 in the $20 \% \mathrm{O}_{2}$ environment. The RFU's of BxPC-3 were 38.35 and 38.31, respectively. This trend continued until $72 \mathrm{~h}$ later (unpublished data). We believe that this hypoxic environment induced HIF-1 $\alpha$ expression from the cells, especially from AsPC-1.

The sensitivity of AsPC-1 and BxPC-3 to GEM are shown in Fig. 4, which shows the absorbance of cell proliferations at each concentration $(\mu \mathrm{M})$ of GEM. BxPC-3 showed a sensitivity to GEM of $0.0001 \mu \mathrm{M}$. In contrast, AsPC-1 showed a sensitivity to GEM of $0.001 \mu \mathrm{M}, 10$ times the density in the $20 \% \mathrm{O}_{2}$ environment. Drug resistance increased in both types of cells in a hypoxic environment, and this tendency was more marked in AsPC-1. These results suggest the possibility that when AsPC-1 was cultured in the hypoxic environment, it secreted HIF-1 $\alpha$ and increased its GEM resistance.

AsPC-1 cells have a mutant heterozygote for HIF-1 $\alpha(\mathrm{C} 1772 \mathrm{C} / \mathrm{T})$ and a wild-type HIF-1 $\alpha(\mathrm{G} 1790 \mathrm{G}) . \mathrm{BxPC}-3$ cells have a mutant heterozygote for HIF-1 $\alpha(\mathrm{G} 1790 \mathrm{G} / \mathrm{A})$ and a wild-type HIF-1 $\alpha(\mathrm{C} 1772 \mathrm{C})$ (Table I). These data suggest the 

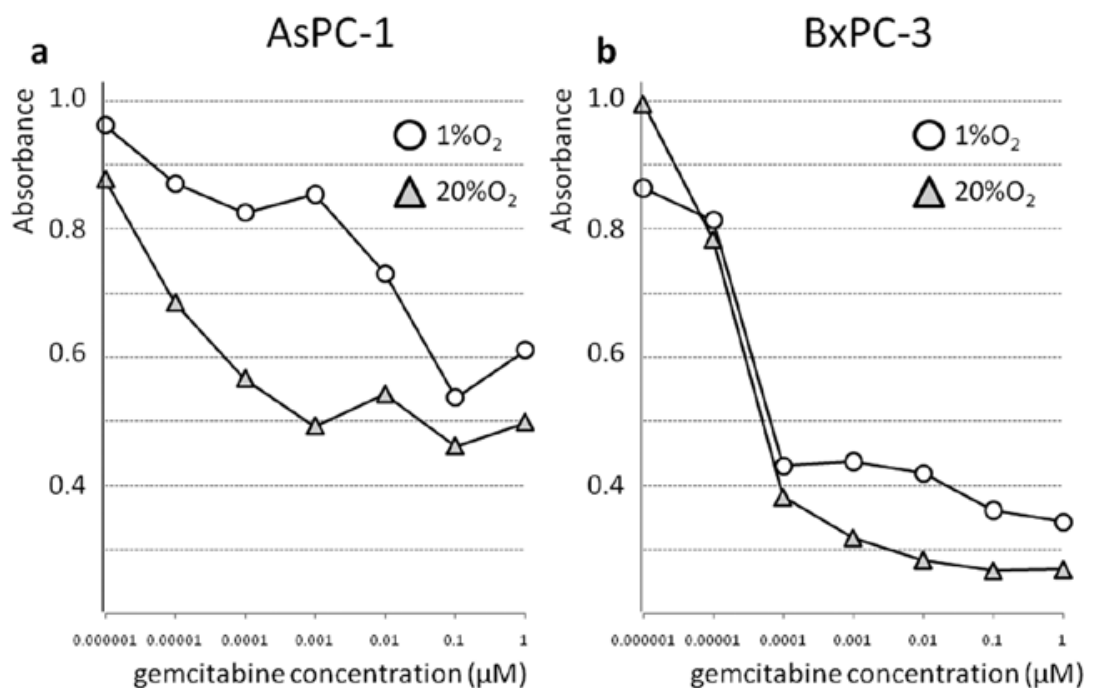

Figure 4. Cell viabilities in $1 \%$ (open circles) and $20 \%$ (gray triangles) $\mathrm{O}_{2}$ environment of (a) AsPC-1 and (b) BxPC-3 cells; $\mathrm{x}$-axis, gemcitabine concentration $(\mu \mathrm{M})$; y-axis, cell viability (absorbance). Drug resistance increased in both AsPC-1 and BxPC-3 in a hypoxic environment (1\% $\left.\mathrm{O}_{2}\right)$, especially in AsPC-1.

Table II. Patient demographics and tumor characteristics.

$$
\text { HIF-1 } \alpha(-), n=25
$$

$\mathrm{HIF}-1 \alpha(+), \mathrm{n}=23$

P-value

Patient characteristics

\begin{tabular}{|c|c|c|c|}
\hline Age, years & $67.6 \pm 7.9$ & $69.3 \pm 8.9$ & $0.50^{\mathrm{a}}$ \\
\hline Tumor site, $\mathrm{Ph} / \mathrm{Pbt}$ & $18 / 7$ & $17 / 6$ & $0.86^{\mathrm{a}}$ \\
\hline Stage, II/III/IVa/IVb & $2 / 13 / 8 / 2$ & $2 / 15 / 3 / 3$ & $0.68^{\mathrm{a}}$ \\
\hline Observation period, days (range) & $653 \pm 612(172-2430)$ & $568 \pm 332(165-1460)$ & $0.51^{\mathrm{a}}$ \\
\hline \multicolumn{4}{|l|}{ GEM chemotherapy } \\
\hline Number of doses (range) & $19.4 \pm 19.3(3-93)$ & $22.7 \pm 15.1(3-64)$ & $0.19^{\mathrm{a}}$ \\
\hline Total dosage, mg (range) & $23,736 \pm 26,607(2,400-130,200)$ & $28,591 \pm 21,165(2,600-89,600)$ & $0.19^{\mathrm{a}}$ \\
\hline \multicolumn{4}{|l|}{ Tumor characteristics } \\
\hline CD34 positive vessels (/area) & $214.8 \pm 130.1$ & $302.0 \pm 212.6$ & $0.30^{\mathrm{a}}$ \\
\hline MIB1 labeling index & $38.0 \pm 20.0$ & $40.1 \pm 16.6$ & $0.54^{\mathrm{a}}$ \\
\hline p53 protein overexpression (+/-) & $14 / 11$ & $14 / 9$ & $0.96^{\mathrm{a}}$ \\
\hline
\end{tabular}

$\mathrm{Ph}$, pancreas head; Pbt, pancreas body to tail; /area, per constant area under the low power magnification. ${ }^{\mathrm{a}}$ Not significant.

Table III. Adverse events.

\section{Grade of AEs}

$0-1 \quad 2>3$ P-value

HIF-1 $\alpha$ protein expression

$\begin{array}{lllll}\text { Negative }(n=25) & 13 & 5 & 7 & 0.63^{a} \\ \text { Positive }(n=23) & 13 & 6 & 4 & \end{array}$

HIF-1 $\alpha$ SNPs

$\begin{array}{lrrrr}\text { No mutation } & 22 & 11 & 11 & \\ \text { Heterogeneous mutation at } \mathrm{C} 1772 \mathrm{C} / \mathrm{T} & 1 & 1^{\mathrm{b}} & 0 & 0.95^{\mathrm{a}} \\ \text { Heterogeneous mutation at G1790G/A } & 3 & 1^{\mathrm{b}} & 0 & \end{array}$

AEs, adverse events; ${ }^{a}$ Not significant; ${ }^{b}$ the same patient. possibility that AsPC-1 cells with a mutation of $\mathrm{C} 1772 \mathrm{~T}$ acquire GEM resistance through the HIF-1 $\alpha$ protein in a hypoxic environment.

On HIF-1 $\alpha$ immunostaining, 25 cases showed negative staining and 23 showed positive staining according to the criteria shown in Fig. 2. The patient demographics and tumor characteristics are described in detail in Table II. There were no statistically significant differences in patient age, tumor site ( $\mathrm{Ph}$, pancreas head; $\mathrm{Pbt}$, pancreas body to tail), followup period, or times and total dosages of GEM between the HIF-1 $\alpha(-)$ group and the HIF-1 $\alpha(+)$ group (Table III). Regarding tumor characteristics, microvessel density was evaluated by the CD34-positive vascular endothelial cells and the proliferative tumor cell ratio by MIB1-positivity and p53 protein overexpression. There were no statistically significant differences in these tumor characteristics, but the number of 


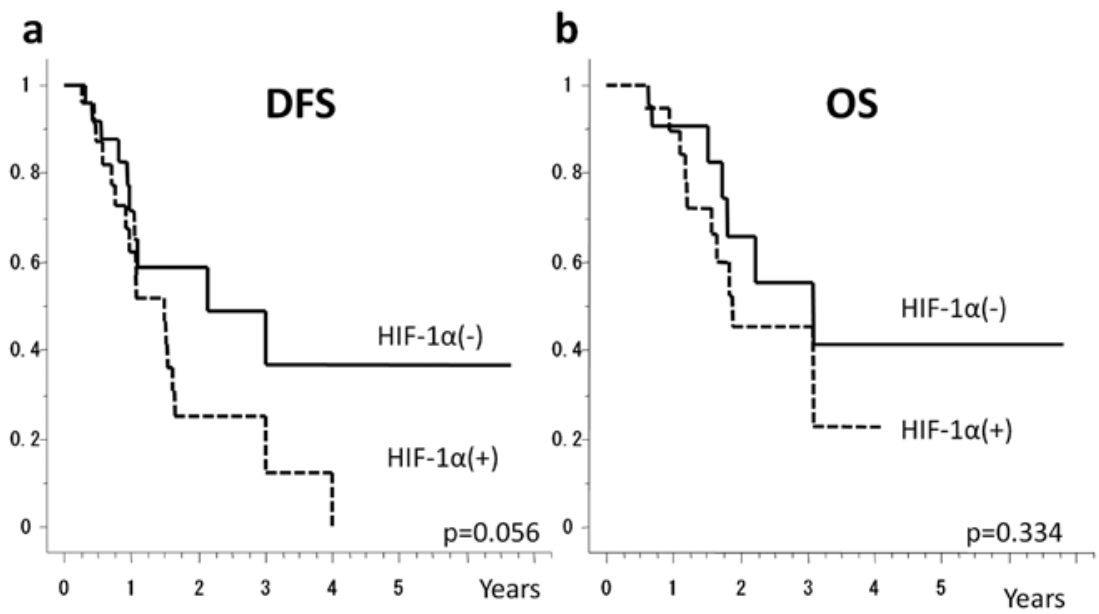

Figure 5. (a) Disease-free survival (DFS) and (b) overall survival (OS) of 25 HIF-1 $\alpha(-)$ patients (continuous lines) and of 23 HIF-1 $\alpha(+)$ patients (dashed lines). In patients with a strong HIF-1 $\alpha$ expression, the recurrence period and overall survival were shorter than those in patients with a HIF-1 $\alpha$ weak expression.

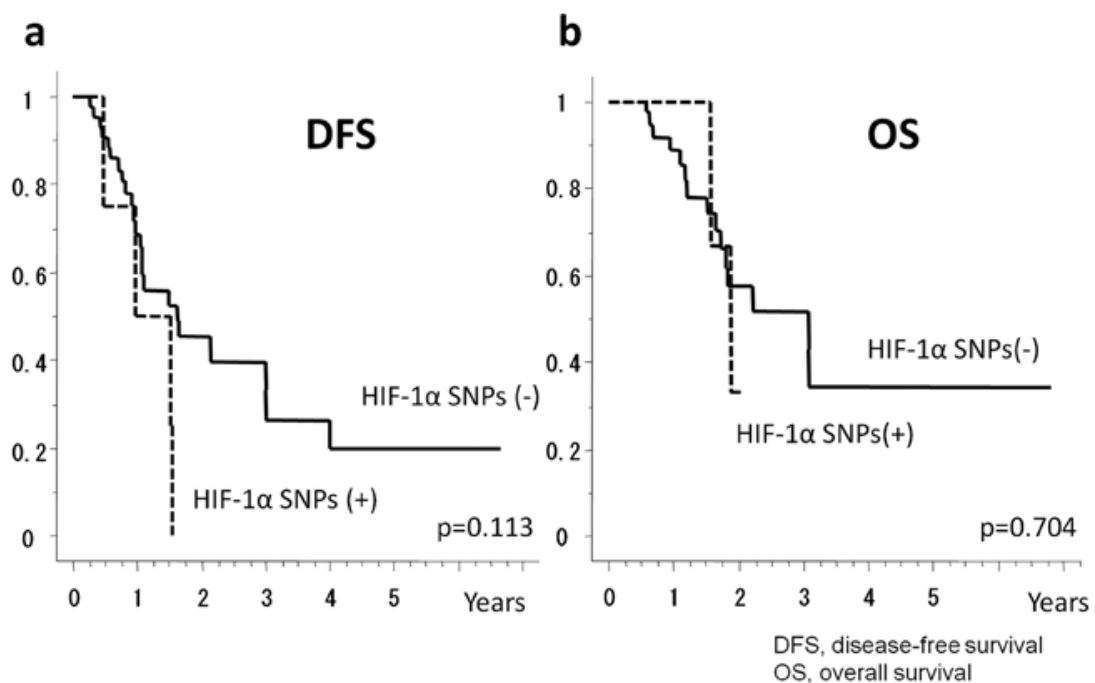

Figure 6. (a) Disease-free survival (DFS) and (b) overall survival (OS) of 43 HIF1 $\alpha$ SNPs(-) patients (continuous lines) and that of 5 HIF1 $\alpha$ SNPs(+) patients (dashed lines).

CD34-positive microvessels and MIB1-positive proliferative cells tended to be higher in the HIF-1 $\alpha(+)$ group than in the HIF-1 $\alpha(-)$ group.

Adverse events $>$ grade 3 occurred due to the biweekly dosage of GEM in 7 (28\%) of 25 patients in the HIF-1 $\alpha(-)$ group [leukopenia $(n=6)$ and fatigue $(n=1)$ ] and in $4(17 \%)$ of 23 patients in the HIF-1 $1 \alpha(+)$ group [leukopenia $(n=3)$ and fatigue $(\mathrm{n}=1)]$. In 1 patient in the HIF-1 $\alpha(-)$ group with grade 3 leukopenia, chemotherapy was declined 5 times, and in 1 patient in the HIF-1 $\alpha(+)$ group with grade 3 fatigue, chemotherapy was declined 15 times. The remaining patients continued treatment, either through therapeutic postponement or G-CSF administration. There were few patients with mutations, that is, only 2 patients with a heterogeneous mutation of HIF-1 $\alpha(1772)$ and 4 patients with a heterogeneous mutation of HIF-1 $\alpha(1790)$. One in 6 cases had heterogeneous mutations of both HIF-1 $\alpha(1772)$ and HIF-1 $\alpha(1790)$.

After the median follow-up periods of 653 days in the HIF-1 $\alpha(-)$ group and 568 days in the HIF-1 $\alpha(-)$ group, disease- free survival (DFS) and overall survival (OS) showed no statistically significant differences between these 2 groups (Fig. 5). However, all the cases of DFS of more than 4 years were in the HIF-1 $\alpha(-)$ group. The DFS and OS were not statistically significantly different between the HIF-1 $\alpha$ SNPs(-) group $(\mathrm{n}=43)$ and the HIF-1 $\alpha$ SNPs $(+)$ group (n=5) (Fig. 6).

\section{Discussion}

We set out to investigate HIF-1 $\alpha$ expression in pancreatic cancer cells and patients who received adjuvant GEM treatment after pancreatectomy for pancreatic cancer, and to evaluate associations among HIF-1 $\alpha$ protein expression, SNPs, tumor related microvessels, GEM medication disorders and outcome.

In recent years, angiogenesis inhibitor drugs with perceived antitumor effects have been developed and used in a clinical setting; an example is bevacizumab, which is an anti-vascular endothelial growth factor (VEGF) antibody. Angiogenesis factors other than VEGF include platelet-derived growth 
factor and basic fibroblast growth factor. However, it appears that VEGF plays the primary role and other factors play supplementary roles $(5,6)$. HIF-1 $\alpha$ is a transcription factor that binds to the hypoxia-response element at about $1 \mathrm{~Kb}$ upstream of the VEGF transcription start site. HIF-1 $\alpha$ is activated under hypoxic conditions, and activates the vascular endothelium via VEGF expression $(5,6)$. Invasive pancreatic cancer is histologically accompanied by interstitial fibrosis and is regarded as a typical hypovascular tumor.

However, clinically, hematogenous metastasis to the liver frequently occurs, resulting in pathological conditions resembling a hypervascular tumor. To explain this contradiction, we established the following hypothesis. The pancreatic parenchyma which shows fibrosis due to pancreatitis associated with pancreatic cancer invasion is placed in a hypoxic condition, in a non-inflammatory state. Under this hypoxic condition, HIF- $1 \alpha$ is activated, and VEGF is expressed at a high level. This promotes the proliferation of new blood vessels, which promotes tumor growth. Therefore, although pancreatic cancer is hypovascular in terms of original blood vessel components, biological behavior is similar to that of hypervascular cancers. This hypothesis supersedes the contradictory biological characteristics of hypovascular tumors and their hematogenous metastases.

In humans with the C1772T mutation of HIF-1 $\alpha$, the risk of type 2 diabetes mellitus is low (7). However, type 2 diabetes mellitus is a risk factor for pancreatic cancer, which suggests an association between the development of pancreatic cancer and the SNPs of HIF-1 $\alpha$. There have been studies on an association between carcinogenesis and HIF-1 $\alpha$ SNPs in cancer in various organs (2,8-11). The $\mathrm{C} 1772 \mathrm{~T}$ and G1790A mutation rates were reported to be 18 and $11 \%$, respectively, in patients with head or neck cancer, and 11 and $8 \%$, respectively, in healthy subjects, with no statistically significant differences between the 2 groups (2). The $\mathrm{C} 1772 \mathrm{~T}$ mutation rates in patients with esophageal squamous cell carcinoma, colorectal cancer, and prostate cancer were reported to be $12 \%$ (8), $0 \%$ (9), and $14 \%$ (10), respectively, with no significant differences from those in healthy subjects. Another study reported a C1772T mutation rate of $84 \%$ and a $\mathrm{G} 1790 \mathrm{~A}$ mutation rate of $55.5 \%$ in patients with renal cancer, with significant differences from those in healthy subjects (99 and 17\%, respectively) (11). In this study, the $\mathrm{C} 1772 \mathrm{~T}$ and $\mathrm{G} 1790 \mathrm{~A}$ mutation rates in pancreatic cancer were $10 \%(1 / 10)$ and $0 \%$, respectively, for pancreatic cancer and $6.3 \%(1 / 16)$ and $6.3 \%(1 / 16)$, respectively, for gallbladder cancer (all heteromutation-type). These results, together with those of previous reports (2,8-11) show a low SNP rate for all cancers, except renal cancer, suggesting the lack of an association between SNPs and carcinogenesis.

Regarding HIF-1 $\alpha$ expression and anticancer drug tolerance, Funato and Takeda (12) inhibited HIF-1 $\alpha$ expression with siRNA using human leukocyte-derived cell strains, and evaluated the recovery of drug sensitivity (adriamycin and AraC). They showed increased HIF-1 $\alpha$ expression in resistant strains and suggested the involvement of HIF-1 $\alpha$ in the acquisition of drug tolerance, although they did not refer to its mechanism. There have been two similar studies showing the recovery of CDDP sensitivity by inhibiting HIF-1 $\alpha$ with siRNA $(13,14)$. One concluded that the acquisition of drug resistance in hypoxia is not associated with drug efflux by $\mathrm{P}$ glycoprotein as a transporter in the cell membrane, but is associated with the
HIF-1 $\alpha$ pathway (13). Another proposed the hypothesis that HIF-1 $\alpha$ expression induces G1 arrest and causes drug tolerance, and showed the recovery of drug sensitivity by inhibiting this arrest (14). In pancreatic cell strains, an increase in GEM sensitivity by introducing an anti-sense HIF-1 $\alpha$ plasmid was reported (3). In patients with gastric cancer, no association between sensitivity to various chemotherapies and HIF-1 $\alpha$ has been shown (15).

It is difficult to explain the acquisition of an anticancer drug-resistance only by expression of HIF-1 $\alpha$, however, HIF-1 $\alpha$ must be the most important protein when reviewing the properties of the carcinoma in the hypoxic environment.

In conclusion, we investigated HIF-1 $\alpha$ expression in pancreatic cancer cells and patients who received adjuvant GEM treatment after pancreatectomy for pancreatic cancer, to evaluate associations among HIF-1 $\alpha$ protein expression, SNPs, tumor related microvessels, GEM medication disorders and outcome. HIF-1 $\alpha$ markedly induced neo-microvascularity in a hypoxic environment and increased drug resistance, but did not provide any evidence regarding GEM medication disorders. Thus, it is difficult to explain the mechanism of the acquisition of anticancer drug resistance using only HIF-1 $\alpha$ expression. HIF-1 $\alpha$ expression is not directly associated with outcome, but in patients with a strong HIF-1 $\alpha$ expression, the recurrence period was shorter than that in those with a HIF-1 $\alpha$ weak expression.

\section{Acknowledgements}

We thank Dr Keiko Shinozawa for her valuable technical assistance. We are also indebted to Mr. Roderick J. Turner, Assistant Professor Edward F. Barroga and Professor J. Patrick Barron, Chairman of the Department of International Medical Communications at Tokyo Medical University, for their review of the manuscript.

\section{References}

1. Tanimoto K, Makino Y,Pereira T and Poellinger L: Mechanism of regulation of the hypoxia-inducible factor- $1 \alpha$ by the von HippleLindau tumor suppressor protein. EMBO J 19: 4298-4309, 2000.

2. Tanimoto K, Yoshiga K, Eguchi H, et al: Hypoxia-inducible factor-1 $\alpha$ polymorphisms associated with enhanced transactivation capacity, implying clinical significance. Carcinogenesis 24: 1779-1783, 2003

3. Chang Q, Qin R, Huang T, Gao J and Feng Y: Effect of antisense hypoxia-inducible factor $1 \alpha$ on progression, metastasis, and chemosensitivity of pancreatic cancer. Pancreas 32: 297-305, 2006.

4. Fechner G, Dederichs F, Schmidt D, Müller S, Vaupel P and Albers P: Hyperoxia-induced improvement of the in vitro response to gemcitabine in transitional cell carcinoma. Anticancer Res 25: 3413-3418, 2005.

5. Forsythe JA, Jiang BH, Iyer NV, Agani F, Leung SW, Koos RD and Semenza GL: Activation vascular endothelial growth factor gene transcription by hypoxia-inducible factor-1. Mol Cell Biol 16: 4604-4613, 1996.

6. Liu Y, Cox SR, Morita T and Kourembanas S: Hypoxia regulates vascular endothelial growth factor gene expression in endothelial cells. Circ Res 77: 638-643, 1995.

7. Yamada N, Horikawa Y, Oda N, Iizuka K, Shihara N, Kishi S and Takeda J: Genetic variation in the hypoxia-inducible factor- $1 \alpha$ gene is associated with type 2 diabetes in Japanese. J Clin Endocrinol Metab 90: 5841-5847, 2005.

8. Ling TS, Shi RH, Zhang GX, Zhu H, Yu LZ and Ding XF: Common single nucleotide polymorphism of hypoxia-inducible factor- $1 \alpha$ and its impact on the clinicopathological features of esophageal squamous cell carcinoma. Chin J Dig Dis 6: 155-158, 2005. 
9. Kuwai T, Kitadai Y, Tanaka S, et al: Single nucleotide polymorphism in the hypoxia-inducible factor-1 $\alpha$ gene in colorectal carcinoma. Oncol Rep 12: 1033-1037, 2004.

10. Chau CH, Permenter MG, Steinberg SM, Retter AS, Dahut WL, Price DK and Figg WD: Polymorphism in the hypoxia-inducible factor-1alpha gene may confer susceptibility to androgen-independent prostate cancer. Cancer Biol Ther 4: 1222-1225, 2005.

11. Ollerenshaw M, Page $T$, Hammonds $J$ and Demaine $A$ Polymorphisms in the hypoxia-inducible factor- $1 \alpha$ gene (HIF1A) are associated with the renal cell carcinoma phenotype. Cancer Genet Cytogenet 153: 122-126, 2004.

12. Funato T and Takeda M: Expression of the hypoxia-inducible factor-1alpha gene in the anticancer drug resistance. Physico-Chem Biol 49 (Suppl): 30, 2005 (In Japanese).
13. Song X, Liu X, Chi W, Liu Y, Wei L, Wang X and Yu J: Hypoxiainduced resistance to cisplatin and doxorubicinin non-small cell lung cancer is inhibited by silencing of HIF-1 alpha gene. Cancer Chemother Phamacol 58: 776-784, 2006.

14. Wu XA, Sun Y, Fan OX, Wang LX, Wang RL and Zhang L: Impact of RNA interference targeting hypoxia-inducible factor-1alpha on chemosensisivity in esophageal squamous cell carcinoma cells under hypoxia. Zhonghua Yi Xue Za Zhi 37: 2640-2644, 2007 (In Chinese).

15. Urano N, Fujiwara Y, Diki Y, et al: Overexpression of hypoxiainducible factor 1alpha in gastric adenocarcinoma. Gastric Cancer 9: 44-99, 2006. 